\title{
SIKAP SOSIAL DAN KEMAMPUAN BERPIKIR KREATIF PESERTA DIDIK KIMIA SMA BERBASIS READING QUESTIONING AND ANSWERING DIPADU CREATIVE PROBLEM SOLVING
}

\section{SOCIAL ATTITUDE AND CREATIVE THINKING ABILITY OF STUDENTS CHEMISTRY OF HIGH SCHOOL BASED ON READING QUESTIONING AND ANSWERING INTEGRATED CREATIVE PROBLEM SOLVING}

\author{
Y. Apriana*1, S. Wahyuningsih ${ }^{2}$, W. Samudera ${ }^{2}$ \\ ${ }^{1}$ Peneliti Pendidikan di Kota Mataram \\ ${ }^{2}$ Peneliti Pendidikan di Kota Mataram \\ *Email: yuyunapriana01@gmail.com
}

Diterima: 23 Mei 2020. Disetujui: 04 Juni 2020. Dipublikasikan: 10 Agustus 2020

\begin{abstract}
Abstrak: Kemampuan berpikir kreatif dan sikap sosial siswa kelas SMAN 8 Mataram masih rendah. Penerapan model pembelajran RQA-CPS dilakukan untuk mengetahui perbedaan sikap sosial dan kemampuan berpikir kreatif peserta didik. Metode penelitian yang digunakan dalam penelitian ini adalah Quasi-Experiment. Data kemampuan berpikir kreatif peserta diperoleh dari nilai test kemampuan berpikir kreatif dan sikap sosial dari angket. Data berpikir kreatif dianalisis dengan ANACOVA menggunakan SPSS versi 25 dan data sikap sosial dianalisis secara deskriptif. Penelitian ini menunjukkan terdapat perbedaan kemampuan berpikir kreatif peserta didik dalam pembelajaran RQA dipadu CPS dengan nilai signifikasi sebesar 0.00 untuk $\mathrm{p}<0$. Selain itu, model pembelajaran RQA dipadu CPS terbukti mampu meningkatkan sikap sosial peserta didik di kelas menjadi lebih baik dalam aspek menerima pendapat teman, memaksa teman untuk menerima pendapatnya, memberi solusi untuk pendapat yang bertentangan serta dapat bekerja sama dengan teman yang berbeda status sosial, suku dan agama.
\end{abstract}

\section{Kata Kunci: Sikap Sosial, Kemampuan Berpikir Kreatif, RQA dipadu CPS}

Abstract: SMAN 8 Mataram is still low. The application of the RQA-CPS learning model is carried out to find out social differences and students' creative thinking abilities. The research method used in this research is Quasi Experiment. Data on participants' creative thinking skills were obtained from test scores. Creative thinking skills and social attitudes from the questionnaire. Creative thinking data were analyzed with ANACOVA using SPSS version 25 and social attitude data were analyzed descriptively. This study shows some differences between students' thoughts in RQA learning combined with CPS with a significance value of 0.00 for $p<0$. In addition, the RQA learning model combined with CPS is proven to be able to increase students' social motivation in class so that they can better learn the help of friends, give friends to accept their opinions, provide solutions for opinions that can be shared with friends of different social status, ethnicity and religion.

\section{Keywords : Social Attitude, Creative Thinking Ability, RQA combined with CPS}

\section{PENDAHULUAN}

Pendidikan merupakan aspek penting dalam menghadapi era globalisasi yang penuh dengan tantangan dan perubahan, dengan pendidikan diharapkan membentuk karakter penerus bangsa yang inovatif, terampil, dan kreatif. Pendidikan kimia mempunyai unsur karakteristik yang khas dan tidak bisa dipisahkan yaitu produk, proses, sikap, aplikasi, dan kreatif.

Untuk menunjang hal tersebut, guru harus memiliki kemampuan dalam melakukan penilaian terhadap peserta didik. Penilaian adalah salah satunya aspek penting dari pembelajaran [1]. Dengan melakukan penilaian, peserta didik dapat mengembangkan potensi secara optimal. Karena itu, penilaian pembelajaran harus dilakukan terus menerus, untuk mengetahui dan memantau perubahan dan kemajuan yang dicapai oleh peserta didik sebagai serta untuk menilai kinerja peserta didik, yang biasanya dilakukan dengan menilai peserta didik hasil pembelajaran[2].

Guru memiliki tujuan dalam melakukan penilaian[3]. Guru menilai peserta didik untuk mengetahui tingkat ketercapaian kompetensi pembelajaran, tujuan lainnya untuk mengetahui kemampuan atau potensi yang dimiliki peserta didik untuk merencanakan pembelajaran terutama dalam menentukan model pembelajaran yang sesuai[4]. Kemampuan atau potensi yang perlu diperhatikan oleh guru adalah kemampuan berpikir kreatif dan sikap sosial peserta didik.

Berpikir kreatif adalah proses interaksi antara elemen kognitif dan afektif [5]. Berpikir kreatif adalah kemampuan untuk menghasilkan ide-ide baru 
[6]. Berpikir kreatif dalam sains dapat membantu peserta didik untuk mencapai langkah-langkah baru dalam sains [7]. Berpikir kreatif dalam sains merupakan kemampuan memahami ide dan konsep baru dalam memberikan rencana kegiatan ilmiah [8]. Berpikir kreatif identik dengan kemampuan untuk menghasilkan ide-ide baru [9]. Berpikir kreatif adalah merancang solusi baru, atau mengekspresikan diri dalam cara yang unik [10]. Berpikir kreatif memiliki lima aspek atau indikator meliputi fluency, flexibility, originality, elaboration, and metaphorical thinking [11].

Selain kemampuan berpikir kreatif, penilaian sikap sosial sangat penting. Penilaian sikap sosial adalah suatu predisposisi yang dipelajari untuk merespon secara positif atau negatif terhadap suatu objek, situasi, dan konsep[12]. Penilaian sikap sosial peserta didik ini penting untuk ditingkatkan[13]. Pada penilaian sikap sosial dengan empat apek yang diukur yaitu mau menerima pendapat teman, memaksa teman untuk menerima pendapatnya, memberi solusi untuk pendapat yang bertentangan serta dapat bekerja sama dengan teman yang berbeda status sosial, suku dan agama[14].

Berdasarkan hasil pengamatan, terhadap model pembelajaran yang telah diterapkan pada peserta didik di Kota Mataram diperoleh informasi bahwa, selama ini pada setiap materi telah diterapkan model pembelajaran yang sama yaitu diskusi informasi dengan metode ceramah dan tanya jawab. Guru menerapkan model pembelajaran tersebut dengan alasan agar peserta didik mudah mengikuti kegiatan pembelajaran serta bagi guru memudahkan dalam pengendalian kelas.

Rata-rata kemampuan peserta didik dalam menerima materi selarna ini adalah baik dan kendala yang dihadapi guru selama ini hanya pada kemampuan peserta didik yang berbeda sehingga sulit mencari model pembelajaran yang tepat untuk mengatasi masalah tersebut. Karakter peserta didik yang heterogen menjadi masalah baru yang dihadapi guru dalam menyampaikan materi, selama ini untuk mengatasi masalah tersebut guru akan memberikan remedial pada akhir pembelajaran.

Dalam proses pembelajaran, selain untuk mengatasi dan mencegah penurunan nilai-nilai moral, sikap yang dimiliki peserta didik juga dapat meningkatkan prestasi peserta didik. Oleh karena itu, guru diharapkan dapat meningkatkan peranannya terutama dalam pembentukan kepribadian peserta didik melalui penilaian sikap dalam pembelajaran di kelas termaksud pada pembelajaran kimia. Pada penilaian sikap khususnya pada penilain sikap sosial, guru mengalami kendala atau masalah dalam merumuskan instrumen penilaian sikap sosial yang digunakan pada setiap materi, dan pada saat mengolah penilaian sikap. Hal tersebut disebabkan karena selama ini guru lebih menekankan pada penilaian pengetahuan dari pada penilaian sikap. Oleh karena itu, dibutuhkan model pembelajaran yang dapat meningkatkan sikap kerjasama dan kolaborasi peserta didik.

Upaya meningkatkan kemampuan berpikir kreatif dan sikap sosial peserta didik yaitu, melalui penggunaan pembelajaran berbasis RQA dipadu CPS. Kelebihan dari model ini karena model pembelajaran ini menekankan pada masalah untuk memperoleh pengetahuan dan konsep yang esensial dari materi pelajaran yang diperoleh dari kegiatan membaca. Pendekatan pembelajaran RQA juga menekankan peserta didik untuk menyiapkan materi dan pengetahuan awal sebelum proses pembelajaran berlangsung[15]. Model CPS dapat meningkatkan kemampuan berpikir kreatif dan kemampuan pemecahan masalah peserta didik[16]. Selanjutnya penerapan pembelajaran berbasis RQA dipadu CPS mampu meningkatkan keterampilan berpikir peserta didik[17].

Berdasarkan latar belakang masalah yang telah diuraikan sebelumnya maka dilakukan penelitian tentang Sikap Sosial dan Kemampuan Berpikir Reatif Peserta Didik Kimia SMA Berbasis Reading Questioning and Answering dipadu Creative Problem Solving.

\section{METODE PENELITIAN}

Metode penelitian yang digunakan dalam penelitian ini adalah Quasi-Experiment. Pada metode penelitian ini kelompok eksperimen dan kelompok kontrol tidak dipilih secara acak karena sebelumnya telah ditentukan homogenitas antar dua kelas tersebut.

Populasi yang digunakan adalah kelas XI SMAN 8 Mataram. Sampel yang akan digunakan diuji dengan uji homogenitas berdasarkan rata-rata nilai UAS murni semester terakhir yaitu semester ganjil tahun pelajaran sebelumnya, kemudian setelah diketahui kelas yang homogen dilanjutkan dengan pengambilan sampel secara acak untuk menentukan kelas eksperimen yaitu kelas XI MIA5 dengan jumlah 32 peserta didik dan kelas kontrol yaitu kelas XI MIA1 dengan jumlah 32 peserta didik.Teknik sampling yang digunakan adalah Simple Random Sampling.

Untuk mengukur kemampuan berpikir kreatif peserta didik diberikan 10 soal berbentuk pilihan 
ganda beralasan. Validasi untuk soal ini menggunakan validasi ahli, kemudian dianalisis menggunakan rumus Akinve.

Pada penilaian sikap sosial menggunakan angket dengan empat apek yang diukur yaitu mau menerima pendapat teman, memaksa teman untuk menerima pendapatnya, memberi solusi untuk pendapat yang bertentangan serta dapat bekerja sama dengan teman yang berbeda status sosial, suku dan agama.

\section{HASIL DAN PEMBAHASAN}

Hasil analisis deskripsi tentang kemampuan berpikir kreatif peserta didik dapat dilihat pada Tabel 1 berikut.

Tabel 1. Hasil Analisis Deskripsi Kemampuan Berpikir Kreatif

\begin{tabular}{|c|c|c|c|c|c|c|}
\hline \multirow[t]{2}{*}{ Skor } & \multirow{2}{*}{$\begin{array}{c}\text { Kela } \\
\mathbf{S}\end{array}$} & \multicolumn{2}{|c|}{ Frekuensi } & \multirow{2}{*}{$\begin{array}{c}\text { Kel } \\
\text { as }\end{array}$} & \multicolumn{2}{|c|}{ Frekuensi } \\
\hline & & $\begin{array}{l}\text { Pre- } \\
\text { Test }\end{array}$ & $\begin{array}{c}\text { Post } \\
\text { - } \\
\text { Test }\end{array}$ & & $\begin{array}{l}\text { Pre- } \\
\text { Test }\end{array}$ & $\begin{array}{l}\text { Post- } \\
\text { Test }\end{array}$ \\
\hline 0 & & 0 & 0 & & 0 & 0 \\
\hline 20 & & 0 & 0 & & 0 & 0 \\
\hline 40 & & 27 & 2 & & 25 & 0 \\
\hline 60 & Eksp & 5 & 28 & Kon & 7 & 10 \\
\hline 80 & $\underset{n}{\text { erime }}$ & 0 & 2 & & 0 & 22 \\
\hline 100 & & 0 & 0 & & 0 & 0 \\
\hline
\end{tabular}

Berdasarkan Tabel 1 di atas, terjadi perbedaan nilai kemampuan berpikir kreatif antara peserta didik pada kelas eksperimen dengan kelas kontrol, dimana skor kemampuan berpikir kreatif peserta didik pada kelas eksperimen lebih tinggi dari kelas kontrol.

Hasil uji Anakova tentang kemampuan berpikir kreatif peserta didik dapat dilihat pada Tabel 2 berikut.

Tabel 2. Uji Anakova Kemampuan Berpikir Kreatif Peserta Didik Antar Kelas

\begin{tabular}{c|c|c|c}
\hline \multicolumn{4}{c}{ Tests of Between-Subjects Effects } \\
\hline \multicolumn{4}{c}{ Dependent Variable: Eksperimen } \\
\hline & Mean & & \\
Source & Square & F & Sig. \\
Corrected Model & 7283.642 & 222.040 & .000 \\
Intercept & 1865.812 & 56.879 & .000 \\
Kontrol & 465.425 & 14.188 & .000 \\
Kelas & 2759.863 & 84.134 & .000 \\
Error & 32.803 & & \\
Total & & & \\
Corrected Total & & & \\
R Squared $=.879$ (Adjusted R Squared $=.875)$ \\
\hline
\end{tabular}

Berdasarkan Tabel 2 di atas, diperoleh perbedaan kemampuan berpikir kreatif peserta didik pada kelas eksperimen dan kelas kontrol dengan hasil sebesar 0.00 untuk $\mathrm{p}<0.01$. Hal ini disebabkan karena pada tahapan integrasi model RQA dipadu CPS terdapat sintaks pertama yaitu membaca. Pada tahap ini peserta didik akan menggali informasi yang terkait pembelajaran yang akan dilakukan. Kegiatan membaca akan membantu peserta didik dalam mengkritisi suatu informasi dan menarik kesimpulan [18]. Selain itu, pembelajarn RQA dipadu CPS dapat meningkatkan motivasi [19]. Model pembelajaran CPS melibatkan keterampilan berpikir, mengungkapkan ide, dan evaluasi [20][21][22]

Diperkuat dengan hasil penelitian [23] model pembelajaran RQA dipadu CPS dapat meningkatkan kemampuan berpikir kreatif siswa, karena model ini menjadikan siswa lebih termotivasi untuk belajar karena siswa dituntut untuk bertanggung jawab masing-masing terhadap keberhasilan belajar kelompoknya untuk menjadi kelompok belajar yang terbaik.

Dengan demikian bahwa pembelajarn RQA dipadu CPS merupakan model pembelajaran yang menggunakan masalah dunia nyata sebagai suatu konteks bagi peserta didik untuk belajar tentang cara berpikir kreatif dan keterampilan pemecahan masalah, serta untuk memperoleh pengetahuan dan konsep yang esensial dari materi pelajaran yang diperoleh dari kegiatan membaca dan memecahkan masalah. Selain itu, pembelajarn RQA dipadu CPS dapat meningkatkan keterampilan berpikir, menumbuhkan inisiatif peserta didik dalam bekerja, motivasi internal untuk belajar, dan dapat mengembangkan hubungan interpersonal dalam bekerja kelompok, serta dapat meningkatkan sikap sosial peserta didik.

Hasil pengukuran sikap sosial peserta didik dapat dilihat pada Tabel 3 berikut.

Tabel 3. Frekuensi Nilai Pengukuran Sikap Sosial Peserta Didik

\begin{tabular}{lcccc}
\hline \multirow{2}{*}{ Kriteria } & \multicolumn{2}{c}{ Kelas } & \multicolumn{2}{c}{ Kelas } \\
& Eksperimen & \multicolumn{2}{c}{ Kontrol } \\
\cline { 2 - 5 } Kurang & $\mathbf{R}_{\mathbf{n}}$ & $\mathbf{R}_{\boldsymbol{\%}}$ & $\mathbf{R}_{\mathbf{n}}$ & $\mathbf{R}_{\boldsymbol{\%}}$ \\
\cline { 2 - 5 } Cukup & 2 & 5 & 15 & 46 \\
Baik & 5 & 16 & 11 & 35 \\
Sangat Baik & 10 & 30 & 3 & 10 \\
& 16 & 48 & 3 & 9 \\
\hline
\end{tabular}

Berdasarkan Tabel 3 di atas, pada penilaian sikap dengan empat apek yang diukur yaitu mau menerima pendapat teman, memaksa teman untuk menerima pendapatnya, memberi solusi untuk pendapat yang bertentangan serta dapat bekerja sama dengan teman yang berbeda status sosial, suku dan agama. Pada kelas eksperimen rata-rata prosentase yang didapat hasil sebesar $5 \%$ untuk kriteria kurang, 
$16 \%$ untuk kriteria cukup, $30 \%$ untuk kriteria baik dan $48 \%$ untuk kriteria sangat baik, sedangkan pada kelas kontrol rata-rata prosentase yang didapat hasil sebesar $15 \%$ untuk kriteria kurang, $35 \%$ untuk kriteria cukup, $10 \%$ untuk kriteria baik dan $9 \%$ untuk kriteria sangat baik. Hal tersebut menunjukkan bahwa aktivitas peserta didik pada kelas eksperimen dengan pembelajaran RQA dipadu CPS lebih baik daripada kelas kontrol.

Dengan demikian, bahwa salah satu alternatif model pembelajaran yang memungkinkan dikembangkannya sikap sosial dan keterampilan berpikir peserta adalah RQA dipadu CPS.

\section{KESIMPULAN}

Berdasarkan hasil dan pembahasan yang telah diuraikan dapat disimpulkan bahwa terdapat perbedaan kemampuan berpikir kreatif peserta didik dalam pembelajaran RQA dipadu CPS dengan nilai signifikasi sebesar 0.00 untuk $p<0$. Selain itu, model pembelajaran RQA dipadu CPS terbukti mampu meningkatkan sikap sosial peserta didik di kelas menjadi lebih baik dalam aspek menerima pendapat teman, memaksa teman untuk menerima pendapatnya, memberi solusi untuk pendapat yang bertentangan serta dapat bekerja sama dengan teman yang berbeda status sosial, suku dan agama.

\section{DAFTAR PUSTAKA}

[1] Maba, W. (2017). Teacher's perception on the implementation of the assessment process in 2013 curriculum. International Journal of Social Sciences and Humanities, vol 1, n. 2, pp. 1-9.

[2] Taras, M. (2005). Assessment -Summative and Formative- Some Theoretical Reflections. British Journal of Educational Studies, vol. 53, n0. 4, pp. 466-478.

[3] Wardani, Astina1, and Susilo. (2018). Pengaruh Gender terhadap Kemampuan Berpikir kreatif Peserta didik SMA Program IPS pada Mata Pelajaran Geografi. Jurnal Pendidikan: Teori, Penelitian, dan Pengembangan, vol. 3, no. 12, pp. 1530-1534.

[4] Anderson, L, W. (2013). Classroom Assessment: Enhancing the Quality of Teacher Decision Making. London: Lawrence Erlbaum Associates, Publisher.

[5] Mkpanang, J, T. (2016). Influence of Creative Style and Gender on Students' Achievement in Physics. Journal of Education and Practice www.iiste.org ISSN 2222-1735 (Paper) ISSN 2222-288X (Online). vol.7, no.12.

[6] De Haan, R. (2009). The impending revolution in undergraduate science education. Journal of
Science Education Technology, vol. 14, pp. 253-270.

[7] Ofsted, P. (2003). Expecting the unexpected: Developing creativity in primary and secondary schools. London: Office for Standards in Education.

[8] Best and Thomas. (2007). Creativity teaching and learning. London: Continuum.

[9] Piaw, C, Y. (2010). Building a test to assess creative and critical thinking simultaneously. Procedia Social and Behavioral Sciences, vol. 2, pp. 551-559.

[10] Wang, Y. (2009). On Cognitive Foundations of Creativity and the Cognitive Process of Creation. International Journal of Cognitive Informatics and Natural Intelligence, vol. 3, no. 4, pp. 1-18.

[11] Treffinger, Young, Selby, and Shepardon. (2002). Assessing Creativity: A Guide for Educators. Florida: The National Research Center on the Gifted and Talented University of Connecticut.

[12] Ajzen, I. (1991). The Theory of Planned Behavior. Organizational Behavior and Human Decision. Processes,vol. 50, pp. 179-211.

[13] Popham, W, J. (1999). Classroom Assessment. Boston:Allyn and Bacon.

[14] Indonesia. Kementerian Pendidikan dan Kebudayaan. Ilmu Pengetahuan Alam. Kementerian Pendidikan dan Kebudayaan. Jakarta: Kementerian Pendidikan dan Kebudayaan, 2014.

[15] Safitri, D. (2016). The Influence of Questioning and Answering Reading Strategies (RQA) combined with Think Pair Share (TPS) Against Learning Outcomes of Class VIII Students of Colomadu State Junior High School 2 in the Circulatory System Material for the 2015/2016 Academic Year. Education Journal of the Muhammadiyah University of Surakarta. vol. 25. no. 7.

[16] Hajiyakhchali, A. (2013). The Efects of Creative Problem Solving Process Training on Academic Well-being of Shaid Chamran University Studens. Near East University, Cyprus. vol. 2, no. 54, pp. 54.

[17] Maftukhin, Dwijanto, and Veronica. (2014). Effectiveness of the Learning Model of Creative Problem Solving Assisted by Learning CDs Against the Ability of Creative Thinking. Unnes Journal of Mathematics Education Department of Mathematics, FMIPA, Semarang State University, Indonesia. vol. 3, no. 1, pp. 34. 
[18] Invone, J. (2010). Critical Thinking, Intelectual Skills, Reasoning And Clinical Reasoning. Retrieved,

[19] Syazali, M. (2015). The Influence of Learning Model of Creative Problem Solving Assisted by Maple II on Mathematical Problem Solving Ability. Al-Jabar: Journal of Mathematics Education, vol. 6, no. 1, 2015, pp. 91-98.

[20] Lubart, T, I. (2001). Models of the creative process: Past, present, and future. Creativity Research Journal, vol. 13, pp. 295-308.

[21] Mumford, K. S. Hester, I. C. Robledo, D. R. Peterson, E. A. Day, D. F. Hougen, and J. D. Barrett. (2012). Mental models and creative problem-solving: The relationship of objective and subjective model attributes. Creativity Research Journal, vol. 24, pp. 311-330.

[22] Treffinger, S. G. Isaksen, and K. B. Stead. (2006). Creative problem solving: An introduction (4th ed.). Waco, TX: Prufrock.].

[23] Samudera, W, Wildan, W, Hadisaputra, S, dan Gunawan, G. (2019). Development of Chemistry Learning Intruments Based on Reading Questiong And Answering Strategy Mixed With Creative Problem Solving. Journal of Physics: Conference Series, 1364 (2019) $012002 I$, doi:10.1088/17426596/1364/1/012002. 